\title{
Kształtowanie układu administracyjnego II Rzeczypospolitej w świetle ówczesnych map \\ Development of the administrative system of Poland's Second Republic as revealed in maps of the period
}

\author{
Piotr Eberhardt $(0)$ \\ Instytut Geografii i Przestrzennego Zagospodarowania im. S. Leszczyckiego PAN \\ ul. Twarda 51/55, 00-818 Warszawa \\ p.ebe@twarda.pan.pl
}

Zarys treści. We wstępnej części artykułu przedstawiono początki kształtowania się granic politycznych i administracyjnych w odrodzonym po I wojnie światowej państwie polskim. W celu określenia ich zasięgu geograficznego dołączono do tekstu osiem oryginalnych map wykreślonych i opublikowanych w latach 1918-1921. Zostały one opisane i skomentowane od strony geograficznej. Mapy te tłumaczą wiele kwestii politycznych a zwłaszcza ukazują uwarunkowania i skutki konfliktów militarnych, które prowadziło państwo polskie ze swoimi sąsiadami. Wytyczone wówczas granice polityczno-administracyjne trwały w zasadzie do 1938 r.

Słowa kluczowe: granice polityczne Polski, mapy polityczno-administracyjne, województwa II Rzeczypospolitej. Keywords: political borders of Poland, political and administrative maps, voivodeships of the Second Republic of Poland.

\begin{abstract}
Wstęp
Formowanie granic II Rzeczypospolitej w jej nowym kształcie terytorialnym trwało kilka lat i wymagało znaczącego wysiłku militarnego i licznych przedsięwzięć na arenie międzynarodowej. Przebieg I wojny światowej był zmienny i prawie do jej zakończenia nieprzewidywalny. Dopiero po nieudanych ofensywach wojsk niemieckich wiosną 1918 r. na froncie zachodnim było już wiadomo, że przewagę uzyskują państwa Ententy. Na froncie wschodnim Rosja była już od 1917 r. wyłączona z wojny i musiała się podporządkować dyktatowi niemieckiemu podyktowanemu w Brześciu Litewskim (Kozłowski, 2008). Zdecydowana większość ziem historycznej Rzeczypospolitej już od końca 1916 r. była pod okupacją Państw Centralnych. Dawało to dużą szanse do działań zjednoczeniowych. Skuteczność ich zależała od wielu czynników zewnętrznych i wewnętrznych ${ }^{1}$.

\footnotetext{
1 Literatura historyczna na temat odzyskania przez Polskę niepodległości, oraz walki o jak najbardziej korzystne granice, która była prowadzona na wielu frontach i prawie ze wszystkimi sąsiadami jest niezmiernie bogata i wielowątkowa. Jedno z zagadnień tego brzemiennego okresu jest traktowane marginalnie przez profesjonalnych historyków, a mianowicie zmiana terytorialnego systemu administracyjnego utworzonego przez państwa zaborcze, na inny dopasowany już do nowych realiów politycznych i ustrojowych niepodległej Polski. Ta kwestia umykała uwadze historyków, zaś geografowie w małym stopniu zajmowali się konsekwencjami I wojny światowej i zmaganiami o granice. Z tego względu w niniejszym artykule będzie skoncentrowana uwaga, na kwestii mniej znanej czytelnikom, a mianowicie z faktem, że wraz z konfliktami granicznymi zachodziła w kraju wielka reforma związana z tworzeniem zrębów jednolitego, trójstopniowego układu administracyjnego kraju, konstruowana już na nowych zasadach ustrojowych.
} 
Przyszłe granice polityczne i ewentualny status polityczny państwa polskiego był ciągle niewiadomy. Zależał od rezultatów wojny na foncie zachodnim. Jednak ta w dużym stopniu iluzoryczna jedność ziem polskich dawała możliwości działania o charakterze integracyjnym. Takim nie tylko symbolem było powołanie Rady Regencyjnej². Te wielokierunkowe działania wpływały mobilizująco na wyniszczone wojną, ale oczekujące bliskiego już przełomu społeczeństwo polskie. Dotyczyło to głównie Królestwa Polskiego i Galicji, ale to terytorium miało stanowić rdzeń przyszłego odrodzonego państwa polskiego. Wykorzystywano wszelkie możliwości organizacyjne, aby w momencie pojawienia się korzystnej koniunktury politycznej podjąć jak najbardziej optymalne działania taktyczne i strategiczne. Równocześnie poza spawami ustrojowymi powstały różnorodne projekty terytorialne. W tym zakresie decydującą rolę odegrał Komitet Narodowy Polski funkcjonujący początkowo w Lozannie a następnie w Paryżu. Stanowił on przedstawicielstwo narodu polskiego wobec państw zachodniej Ententy (Wapiński, 1995). Opracowano wówczas pod kierownictwem Romana Dmowskiego projekt przyszłych granic państwa polskiego. Wielokrotnie był on prezentowany ma forum zagranicznym a następnie stał się oficjalnym dokumentem delegacji polskiej na Konferencji w Wersalu (Wapiński, 1995). Powstawały w okupowanym kraju autorskie projekty na których wykreślano granice przyszłej Polski. Były to między innymi projekty następujących autorów: J. Tomaszewski, A. Janowski. Cz. Jankowski, W. Wakar, E. Romer, W. Skarga-Dobrowolski. Niektóre z nich wysuwały postulaty małorealistyczne, gdyż punktem odniesienia były granice historycznej Rzeczypospolitej z 1772 r., inne bardziej minimalistyczne nawiązywały do obszarów etnicznej Polski, powiększonymi o Wilno i Lwów (Eberhardt, 2018). Było również wiadomo, że Polska będzie krajem republikańskim, demokratycznym o ustroju parlamentarnym. Co później było oficjalnie zadekretowane w konstytucji marcowej z 1921 r. Wszystko to razem świadczy, że naród polski był mentalnie przygotowany do życia we własnym suwerennym państwie. Te dość istotne informacje dowodzą, że elita intelektualna Polski była dobrze przygotowana do zorganizowania nowoczesnego państwa, tak od strony ustrojowej jak i administracyjnej.

Najważniejszym zadaniem wewnętrznym, które stanęło przed władzami nowego państwa polskiego było utworzenie unitarnego organizmu państwowego o jednolitej zcentralizowanej administracji terytorialnej. Należało to od podstaw zorganizować na obszarze, który stanowił przez ponad sto lat peryferyjne pogranicze Rosji, Niemiec i Austrii. Te działania podjęto bezpośrednio po odzyskaniu przez Polskę niepodległości w listopadzie 1918 r. Utworzenie jednolitego układu ustrojowego i administracyjnego było celem nadrzędnym, gdyż bez niego odrodzone państwo nie mogłoby sprawnie funkcjonować w tak trudnej sytuacji politycznej ${ }^{3}$. Zachowanie dotychczasowych zasad terytorialnych i prawnych istniejących w państwach zaborczych było nie tylko niewskazane, ale i niebezpieczne, ze względów zarówno pragmatycznych jak i pryncypiów ideowo-narodowych. Utrwalone przez dziesięciolecia układy kompetencyjno-administracyjne służyły interesom

${ }^{2}$ W polskiej historiografii nie docenia się znaczenia Rady Regencyjnej dla scalenia politycznego ziem polskich. Powstała za zgodą okupacyjnych władz niemieckich i austriackich. Powołała ona 4.02.1918 Radę Stanu, która przygotowała liczne dokumenty o podstawach ustrojowych przyszłego państwa polskiego. O ważnej roli Rady Regencyjne w tworzeniu zrębów polskiej administracji: (Piszczkowski, 1969; Ajnenkiel, 1972, 1982).

${ }^{3}$ Współcześni polscy politycy i intelektualiści mieli pełne rozeznanie o strukturze administracyjnej i warunkach gospodarczo-społecznych na ziemiach polskich. Mieli też konkretne programy polityczne. Podejmowali decyzje na podstawie wszechstronnej dokumentacji faktograficznej i statystycznej. Bezpośrednio po uzyskaniu przez Polskę niepodległości ukazało się wiele opracowań, które są poświęcone tej tematyce (Kutrzeba, 1921; Kumaniecki, 1921,1924; Bukowiecki, 1922; Dmowski, 1925). 
i potrzebom trzech państw zaborczych, zmierzając do zniewolenia i eksploatacji ziem polskich. Utrzymanie za długo reliktów panowania tych państw utrudniłoby unifikacje kraju w nowych granicach i miałoby negatywne skutki przy tworzeniu racjonalnego systemu ustrojowo-terytorialnego. Zdawano sobie jedynie sprawę, że jest to zadanie trudne i nie może polegać na improwizacji i nieprzemyślanych decyzjach. Zatarcie starego systemu politycznego i podziału administracyjnego wymagało pewnego okresu przejściowego, w którym zachowano pewne zaszłości historyczne i odrębności regionalne.

Wydarzenia związane z tworzeniem nowego ładu administracyjnego i prawnego były na bieżąco ogłaszane i monitorowane a następnie dokumentowane ${ }^{4}$. W dużym stopniu te archiwalia się zachowały i mogą być obiektem analiz i ocen wyjaśniających ${ }^{5}$. Ważną rolę odgrywała w tym zakresie dokumentacja kartograficzna, która niestety była stosunkowo uboga. Wzbudzała ona również mniejsze zainteresowanie badaczy, może dlatego, że było wśród nich mało profesjonalnych geografów. Obecnie po wielu latach przypomnienie niektórych z tych map może stanowić cenny materiał do zrozumienia wielu kwestii merytorycznych dotyczących formowania się granic państwa i polskiej administracji terytorialnej.

Wykreślane mapy w okresie kształtowania się granic i ustroju terytorialnego II Rzeczypospolitej miały wielorakie zadania do spełnienia. Obok znaczenia utylitarnego odgrywać miały pewną rolę propagandową i edukacyjną. Głównie powstawały w kraju z inicjatywy władz nowego państwa. Rozpowszechniane zagranicą miały uzasadnić, że państwo polskie ma prawo do egzystencji w uznanych i trwałych granicach politycznych. Funkcjonowanie jednostek administracyjnych różnego szczebla podporządkowanych centralnym władzom państwa polskiego świadczyło już o przezwyciężeniu spuścizny zaborów i konsolidacji nowego ładu prawnego. Opracowane wówczas nieliczne ujęcia kartograficzne wykazywały sytuacje w ściśle określonym przekroju czasowym, więc ich prezentacja w ujęciu dynamicznym może wyjaśnić w pewnym zakresie ewolucje przeobrażeń politycznych i administracyjnych. Władze centralne wykorzystywały wówczas głównie mapy państw zaborczych ${ }^{6}$, oraz monumentalny, trójjęzyczny atlas geograficzno-statystyczny Eugeniusza Romera (1916). Na jednej z map opracowanych przez autora ukazano przedwojenny podział administracyjny ziem polskich w ujęciu jednostek powiatowych. Stanowił on podstawę zarządzania krajem, gdyż jednostki wyższego szczebla wojewódzkiego, były w fazie kształtowania się i zamętu organizacyjnego. Atlas ten był prezentowany na forum zagranicznym, w tym na konferencji wersalskiej.

\footnotetext{
${ }^{4}$ Monumentalnym dziełem był zbiór dokumentów wydanych bezpośrednio po wojnie w 1920 r. Stanowi on niewyczerpane źródło informacji o prowadzonej przez władze centralne polityki integracyjnej zmierzającej do faktycznego zjednoczenia ziem polskich (Kumaniecki, 1921).

${ }^{5}$ Dokumenty te w różnych zestawach problemowych były później wielokrotnie przypominane. Głównie działo się to w latach okrągłej rocznicy, związanej z rokiem 1918 lub 1920 (np. Szwarc i Turkowski, 2000).

${ }^{6}$ Służby kartograficzne i statystyczne w trzech państwach zaborczych stały na wysokim poziomie. W państwie niemieckim i austriackim spisy ludności odbywały się co 10 lat i zawierały ilustracje kartograficzną. W carskiej Rosji spis się odbył w 1897 r. i jest przez specjalistów oceniany bardzo wysoko. Zawierał dużo wiarygodnych danych statystycznych w układzie ówczesnych jednostek administracyjnych. Dotyczyło to Królestwa Polskiego i guberni na wschód od niego położonych.
} 


\section{Podziały administracyjne ziem polskich w okresie zaborów}

Ziemie Królestwa Polskiego, zwanego przez władze carskie od lat 80 XIX w. Krajem Nadwiślańskim (ros. Priwislinskij kraj) dzieliły się na 10 guberni: kaliską, siedlecką, łomżyńską, piotrkowską, warszawską, lubelską, suwalską, kielecką, płocką i radomską ${ }^{7}$. Przed I wojną światową (w 1912 r.) przeprowadzono na tym obszarze jedną zmianę a mianowicie ze wschodnich terenów guberni lubelskiej i siedleckiej (wcześniej zlikwidowanej) utworzono gubernię chełmską, którą dołączono do gubernatorstwa kijowskiego. W pokoju brzeskim niemieckie władze okupacyjne przekazały ją tworzącemu się państwu ukraińskiemu. Pozostałe ziemie wschodnie I Rzeczypospolitej, włączone w traktatach rozbiorowych do Cesarstwa Rosyjskiego stanowiły od 1815 r. część europejskiej Rosji i obejmowały 9 guberni (kowieńską, wileńską, mińską, witebską, mohylewską, grodzieńską, wołyńską, podolską i kijowską) Mieszkało tam wielu Polaków zmierzających do połączenia tych ziem z odrodzoną Rzeczypospolitą. Obwód białostocki był poza granicami Królestwa Kongresowego i należał do guberni grodzieńskiej.

Ziemie polskie zaboru pruskiego wchodziły w skład Wielkiego Księstwa Poznańskiego, zwane były Prowincją Poznańską i dzieliły się na dwie regencje: poznańską i bydgoską. Polskie Pomorze zwane wschodnim, należało do tzw. Prowincji Prusy Zachodnie i dzieliło się na regencje gdańską i kwidzyńską. Historyczny Śląsk nie należący do I Rzeczypospolitej obejmował trzy regencje: legnicką, opolską i wrocławską. Prowincja Prusy Wschodnie obejmowała zarówno ziemie należące w 1772 r. do Rzeczypospolitej (Warmię oraz województwo malborskie i chełmińskie), jak i te, które od 1657 r. uwolniły się od zależności od Polski, tworząc później Królestwo Pruskie. Przed I wojną światową Prusy Wschodnie dzieliły się na regencje: królewiecką, gąbińską i olsztyńską.

W zaborze austriackim nie było prowincji zbliżonych do szczebla wojewódzkiego. Początkowo ziemie te tworzyły tzw. Kraj Koronny podzielony na 19 okręgów zwanych cyrkułami. W ramach reformy przeprowadzonej w 1846 r. Galicje podzielono na dwa okręgi administracyjne: krakowski i Iwowski. Składały się one, po likwidacji w 1865 r., z tzw. urzędów okręgowych, z licznych jednostek powiatowych mających dużą autonomie administracyjną. Odrębnym tworem administracyjnym był Śląsk Cieszyński wchodzący wraz ze Śląskiem Opawskim w skład Królestwa Czech jako Śląsk Austriacki.

Szybkie ujednolicenie tego skomplikowanego układu administracyjnego było zadaniem złożonym. Powstało wiele koncepcji autorskich, które rozpatrywały nie tylko kwestie terytorialne ale również prawno-ustrojowe. Wszystkie postulowały likwidacje podziałów istniejących w państwach zaborczych i stworzenie jednolitego trójstopniowego podziału administracyjnego kraju złożonego z województw, powiatów i gmin . Warunkiem podstawowym spełnienia tego zamierzenia było uzyskanie niepodległości i pełnej podmiotowości politycznej.

7 Zmiany podziału administracyjnego w Królestwie Polskim zilustrowano na wielu mapach (Trzebiński, 1956).

8 Proces formownia się układu administracyjnego II Rzeczypospolitej w ciągu czterech przełomowych lat (1918-1922) został przedstawiony w sposób syntetyczny w odrębnym tomie wydanym pod kierunkiem A. Kuklińskiego i P. Swianiewicza (Leszczyńska, 1990; Kukliński i Swianiewicz, 1990). 


\section{Początki kształtowania polskiej administracji terytorialnej}

Sygnałem, że sytuacja ulega zmianie i pojawiają się sprzyjające warunki do utworzenia polskiej administracji terenowej były wydarzenia, które zaszły na Śląsku Cieszyńskim. Powołana 19.10.1918 r. Rada Narodowa Śląska Cieszyńskiego, wystąpiła z oficjalną deklaracją utworzenia tymczasowej polskiej władzy państwowej i podziału Księstwa Cieszyńskiego na część polską i czeską. Uzgodniono ze stroną czeską, że podział ten zostanie przeprowadzony na podstawie kryterium etnicznego, co później nie było dotrzymane przez władze Pragi. Powstał więc pierwszy niewielki obszar Polski wyzwolony od władzy jednego z zaborców (Pobóg-Malinowski, 1967, s. 136).

Pierwsze konkretne i samodzielne zapowiedzi dotyczące całkowitej likwidacji władzy zaborczej, względnie okupacyjnej oraz utworzenia już niezależnej, polskiej administracji terenowej podjęto 28.10.1918 r. w Krakowie. Zebrali się w tym dniu polscy posłowie do parlamentu austriackiego i powołali do życia tzw. Polską Komisje Likwidacyjną. W skład jej wchodzili przedstawiciele różnych orientacji politycznych, zaś główną rolę odgrywał Wincenty Witos. Zmierzali oni podporządkować sobie lokalną administracje na terenie Galicji i Śląska Cieszyńskiego i utworzyć namiastkę państwa polskiego, które miało być lojalne w nieodległej już przyszłości w stosunku do nadrzędnych władz suwerennego państwa polskiego, mającego stolicę w Warszawie. Polska Komisja Likwidacyjna zamierzała powołać stosunkowo szybko Sejm Konstytucyjny państwa polskiego. W pierwszych dniach listopada opanowano zachodnią Galicje, południowe powiaty Królestwa Polskiego oraz niektóre gminy Orawy i Spisza.

Równocześnie Rada Regencyjna w Warszawie podjęła działania zmierzające do uzyskania pełnej i nieograniczonej kontroli nad ziemiami Królestwa Polskiego oraz Galicji. Podjęte przez nią działania były mało skuteczne, gdyż jej dotychczasowa lojalność wobec okupacyjnej władzy niemieckiej nie uwiarygodniała jej w oczach społeczeństwa polskiego. Było to jedną z przyczyn ukonstytuowania się w dniu 6.11.1918 r. w Lublinie Tymczasowego Rządu Ludowego Republiki Polskiej. Utworzono Rząd pod kierunkiem działacza socjalistycznego Ignacego Daszyńskiego i ogłoszono manifest proklamujący powstanie jednolitego państwa polskiego. Rząd ten istniał zaledwie kilka dni, gdyż przekazał swoje uprawnienia w ręce Józefa Piłsudskiego, będącego od 10.11.1918 r. w Warszawie. Podobnie uczyniła to 14.11.1918 r. Rada Regencyjna. Następnym krokiem podjętym przez J. Piłsudskiego było powołanie 18.11.1918 r. nowego Rządu Polskiego pod przywództwem Jędrzeja Moraczewskiego. Program nowego Rządu ogłoszono w deklaracji z 22.11.1918 r., której to akt oddawał władzę J. Piłsudskiemu jako Tymczasowemu Naczelnikowi Państwa, aż do czasu zwołania Sejmu Ustawodawczego. Wymagało to stworzenia zcentralizowanej władzy administracyjnej dla stopniowo wyzwalanych ziem polskich, które dotychczas stanowiły formalnie integralną część trzech państw zaborczych lub okupacyjnych. Początkowo opanowano dużą część Królestwa Polskiego i zaboru austriackiego. Na znacznych obszarach Królestwa znajdowały się okupacyjne wojska niemieckie, które stopniowo wycofywały się na zachód. Na terenach wschodniej Galicji sytuacja była nieustabilizowana, gdyż tam uaktywniły się zbrojne formacje ukraińskie, które zamierzały utworzyć niepodległe państwo ukraińskie9 .

\footnotetext{
${ }^{9}$ Przełomowy listopad 1918 r. był obiektem licznych prac polskich historyków (np. Łossowski, 1998).
} 
Równocześnie z wyzwoleniem się ziem zaboru rosyjskiego i austriackiego i tworzeniem się zrębów samodzielnej administracji polskiej rozpoczęły się działania organizacji polskich w zaborze pruskim. Posłowie polscy tworzący tzw. Koło Polskie w parlamencie Rzeszy Niemieckiej zaczęli się domagać przyłączenia ziem zaboru pruskiego do tworzącej się Polski. Wysunęli postulat oderwania od Rzeszy Niemieckiej „polskich powiatów Górnego i Średniego Śląska, Poznańskiego, Prus Zachodnich i polskich powiatów Prus Wschodnich" (Topolski, 1981, s. 624). Rewolucja listopadowa w Niemczech obaliła monarchie i przekształciła Niemcy w republikę. Nadal stała ona na stanowisku niezmienności wschodnich granic Niemiec. W przeddzień kapitulacji Niemiec, czyli 10.11.1918 r. powstała polska „Rada Ludowa”, będąca reprezentantem ludności polskiej w Niemczech. Przedstawiciele jej w połowie listopada udali się do Warszawy z deklaracją o włączeniu ziem zaboru pruskiego do Odrodzonej Rzeczypospolitej. Miało to wówczas jedynie charakter symboliczny. W drugiej połowie listopada w zaborze pruskim odbyły się wybory, które umożliwiły przedstawicielom ludności polskiej uzyskanie samodzielności lokalnej w wielu jednostkach miejskich, gminnych i powiatowych. Momentem jednak zwrotnym był przyjazd 27.12.1918 r. do Poznania Ignacego Paderewskiego. Wybuchło powstanie, które wyzwoliło centralną cześć Wielkopolski. Po tym historycznym wydarzeniu oczekiwano na werdykt graniczny mocarstw zachodnich.

W tym samym czasie ludność polska tzw. ziem zabranych, czyli Litwy i Rusi oraz Galicji Wschodniej, należącej do zaboru austriackiego rozpoczęła aktywną działalność na rzecz włączenia całych rozległych Kresów Wschodnich do Polski. Długo trwały walki o Lwów i dopiero po ofensywie wojsk polskich opanowano tereny Galicji, aż po Zbrucz. Równocześnie wojska polskie stopniowo przesuwały się na wschód od strony Kongresówki i do lata 1919 r. opanowano Wileńszczyznę, Polesie, Mińszczyznę, Wołyń i dużą część Podola. Na wyzwalanych terenach tworzono zręby tymczasowej polskiej administracji. Powołano do życia Zarząd Cywilny Ziem Wschodnich i Urząd Generalnego Komisarza Zarządu Cywilnego Ziem Wschodnich.

Najważniejszą jednak kwestią było ujednolicenie administrowania nad całym wyzwolonym krajem i zatarcie granic zaborczych, czyli pełne zjednoczenie ziem byłego Królestwa z zaborem pruskim i austriackim. Dekretem Naczelnika Państwa z 10.01.1919 r. zlikwidowano Polską Komisję Likwidacyjną i powołano do życia „Komisje Rządzącą dla Galicji, Śląska Cieszyńskiego oraz Górnej Orawy i Spisza" jako organu kontrolującego i prawodawczego. Dla szybszej unifikacji terytorialnej zaboru rosyjskiego z austriackim utworzono Generalną Delegaturę Rządu, mające uprawnienia podobne jak dawniej namiestnik Galicji. Początkowo nie wyłączono jednak z Królestwa jej południowych powiatów ciążących historycznie i funkcjonalnie do Krakowa.

Znacznie dłużej trwała odrębność regionu poznańskiego. Początkowo utworzona Naczelna Rada Ludowa, oraz jej organ wykonawczy - trójosobowy Komisariat utrzymywały stary niemiecki system administracyjny, oczekując na werdykt wersalski. Dopiero po nim, 11.07.1919 r., zniesiono granicę celną odgradzającą Wielkopolskę od tzw. Kongresówki i na podstawie kolejnej ustawy z 01.08.1919 r. podzielono tymczasowo zabór pruski na województwo poznańskie i pomorskie, przyznając im uprawnienia i kompetencje dotychczasowych niemieckich zarządców prowincji, względnie regencji. Powołano jednocześnie z siedzibą w Warszawie Ministerstwo byłej dzielnicy pruskiej, mające dużą autonomie w zarządzaniu i administracji. 


\section{Proces delimitacji granic administracyjnych w świetle źródeł kartograficznych}

Uprawomocnieniem nowej władzy państwa polskiego miały być demokratyczne wybory. Odbyły się stosunkowo szybko, gdyż 26.01.1919 r. Wybrano wówczas Sejm Ustawodawczy Rzeczypospolitej Polskie liczący łącznie 340 posłów, w tym z byłego Królestwa Polskiego - 226, z Małopolski, czyli z byłego zaboru austriackiego - 70. Dodatkowo weszło do Sejmu 44 posłów z dawnego parlamentu austriackiego, wśród których było 28 posłów ze wschodniej Galicji. Dobrano dodatkowo 16 byłych posłów parlamentu niemieckiego (z poznańskiego - 9, z Górnego Śląska - 5 i z Pomorza - 2 (Pobóg-Malinowski, 1967, s. 177). Dla potrzeb wyborczych wykreślona została mapa zatytułowana: Republika Polska. Mapa okręgów wyborczych do Sejmu Ustawodawczego (ryc. 1) ${ }^{10}$.

Była to przypuszczalnie pierwsza mapa administracyjna, która powstała już w odrodzonej II Rzeczypospolitej. Przedstawiono na niej w zasadzie układ przedwojennych powiatów, który pokrywał się z okręgami wyborczymi. Jest ona interesująca, gdyż ukazane na mapie nowe państwo nie posiada zewnętrznych granic politycznych. Nie było bowiem wiadomo, jak one będą w przyszłości wytyczone w wymiarze geograficznym. Na mapie ukazano cały obszar Królestwa Polskiego i Galicji ze Spiszem, Orawą i Śląskiem Cieszyńskim. Nie znano jeszcze werdyktu mocarstw zachodnich wobec pokonanych Niemiec, wyodrębniono z zaboru pruskiego Wielkopolskę i Pomorze Gdańskie, następnie polskojęzyczną Opolszczyznę tzw. Śląsk Górny. Oczekiwano, że granica polsko-niemiecka na odcinku centralnym i północno-zachodnim będzie dla Polski korzystniejsza, niż to się później stało. Na pewnych odcinkach nawiązano do zachodnich granic I Rzeczypospolitej a nawet ją przekroczono. Kresy Wschodnie w tym czasie były poza jurysdykcją polskiej władzy centralnej a wojska polskie dopiero zamierzały przesunąć się na wschód i opanować te rozległe tereny, które opuszczały wojska niemieckie a nie wkroczyła jeszcze Armia Czerwona. To ujęcie kartograficzne jest ważne, gdyż ujawnia sytuacje całkowicie niestabilną politycznie i administracyjnie.

W połowie lutego 1919 r. ukonstytuowały się ostatecznie trzy naczelne instytucje państwa: Naczelnik Państwa, Rada Ministrów i Sejm Ustawodawczy. Powstało jednolite, zjednoczone państwo polskie, które jedynie nie miało ustalonych granic zewnętrznych. Te dopiero zostały wytyczone ostatecznie, po zakończonej wojnie polsko-bolszewickiej i włączeniu do Polski Ziemi Wleńskiej i wschodnich powiatów Górnego Śląska.

Problem wewnętrznej organizacji terytorialnej był zadaniem trudnym i kontrowersyjnym. Ścierały się różne poglądy i opinie. Niemniej wszystkie odpowiedzialne ugrupowania stały na stanowisku utworzenia unitarnego, zcentralizowanego państwa polskiego o jednolitej i zhierarchizowanej władzy administracyjnej. W miarę stabilizacji sytuacji wewnętrznej istniejący tymczasowy podział był zastępowany już organami mającymi uprawnienia konstytucyjne. Na podstawie ustawy o organizacji władz administracyjnych na terenie byłego Królestwa Polskiego z 2.08.1919 r. utworzono województwa: warszawskie, łódzkie, kieleckie, lubelskie i dodatkowo, usytuowane poza Królestwem - białostockie. Wyodrębniono na prawach odrębnego województwa Warszawę jako stolicę odrodzonego państwa. Nadal trwała pewna tymczasowość, gdyż toczyła się dyskusja na temat liczby województw, ich rozgraniczeń a nawet ich stolic ${ }^{11}$.

\footnotetext{
10 Mapa ta została zamieszczona w jubileuszowym albumie (Skoczek, 2018, s. 22).

11 Zastanawiano się na przykład czy stolicą województwa łódzkiego nie powinien być jak dotychczas Piotrków Trybunalski. Podobnie pobliski Kalisz domagał się uprawnień wojewódzkich. Tego typu kontrowersji było więcej.
} 


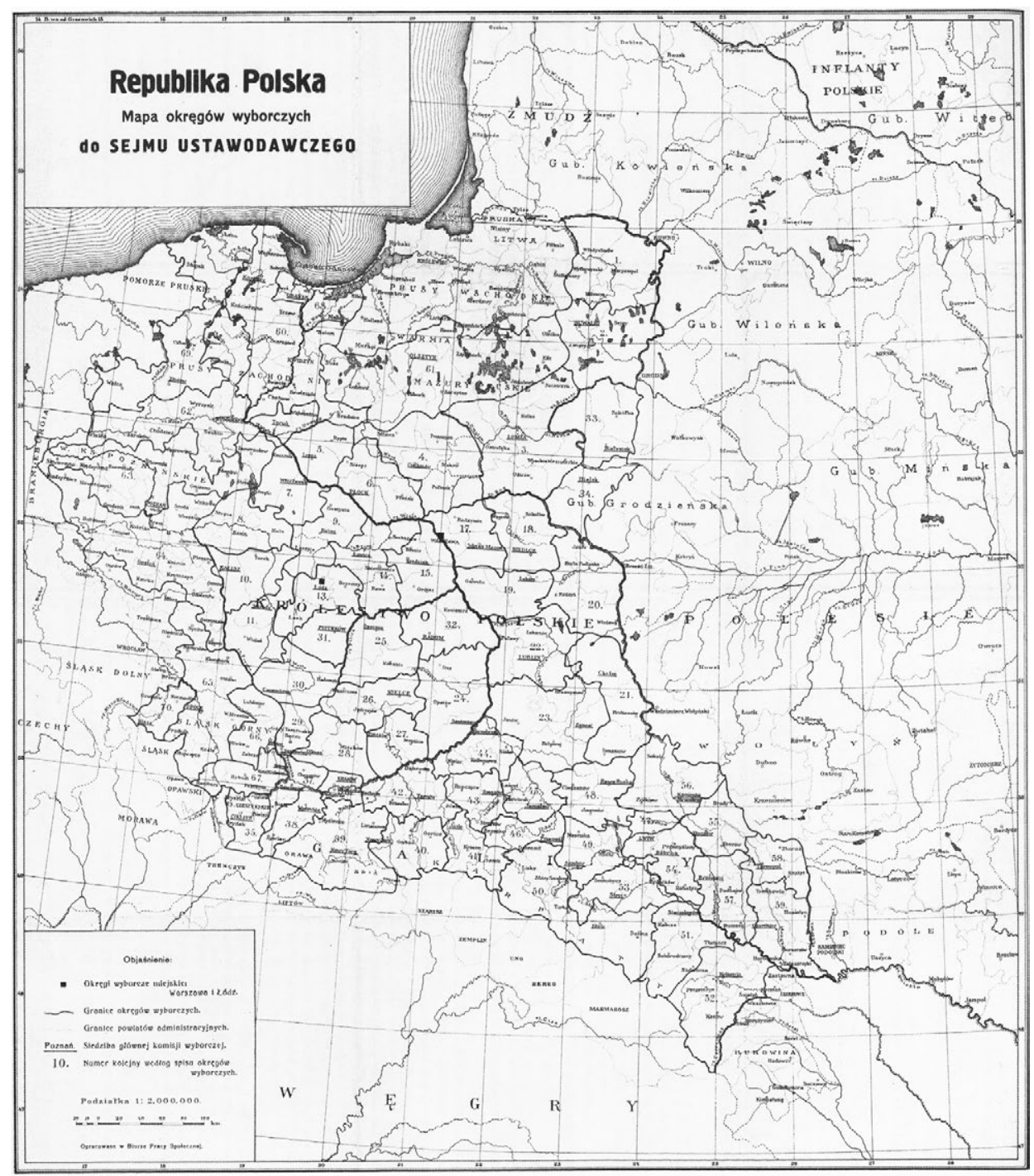

Ryc. 1. Mapa okręgów wyborczych do sejmu ustawodawczego, $1919 \mathrm{r}$. Map of constitutencies electing the Legislative Sejm of 1919 Źródło: Republika Polska. Mapa okręgów wyborczych do Sejmu Ustawodawczego, 1919, Warszawa, Biblioteka Narodowa, sygn. ZZK 27041 / Source: Republika Polska. Mapa okręgów wyborczych do Sejmu Ustawodawczego, 1919, Warsaw, National Library, Ref. ZZK 27041.

W sytuacji jeszcze nie w pełni ustabilizowanej w kraju zapadł rozstrzygający werdykt na Konferencji Pokojowej w Paryżu (który uprawomocnił się ostatecznie 28.06.1919 r.). Ustalono na niej przebieg przyszłej granicy polsko-niemieckiej. Postanowiono dodatkowo, że na Górnym Śląsku i w południowych Prusach Wschodnich odbędą się plebiscyty. Bezpośrednio po tym przełomowym wydarzeniu historycznym została opublikowana mapa pokazująca zarys terytorialny postulowanego państwa polskiego. Została ona zatytułowana: „Mapa 
ziem polskich” (a nie „państwa polskiego”) a autorem był Bernard Połoniecki. Jako miejsce wydania podano Warszawę i Lwów, ale sam autor i jego firma o nazwie „Księgarnia Polska” usytuowana była we Lwowie (ryc. 2). Na tej mapie kolorem pomarańczowym zamalowano tzw. „ziemie polskie”, które obejmowały terytorium zaboru pruskiego uzyskane w Wersalu, już z dokładnie wytyczoną granicą polsko-niemiecką, następnie Królestwo Kongresowe oraz

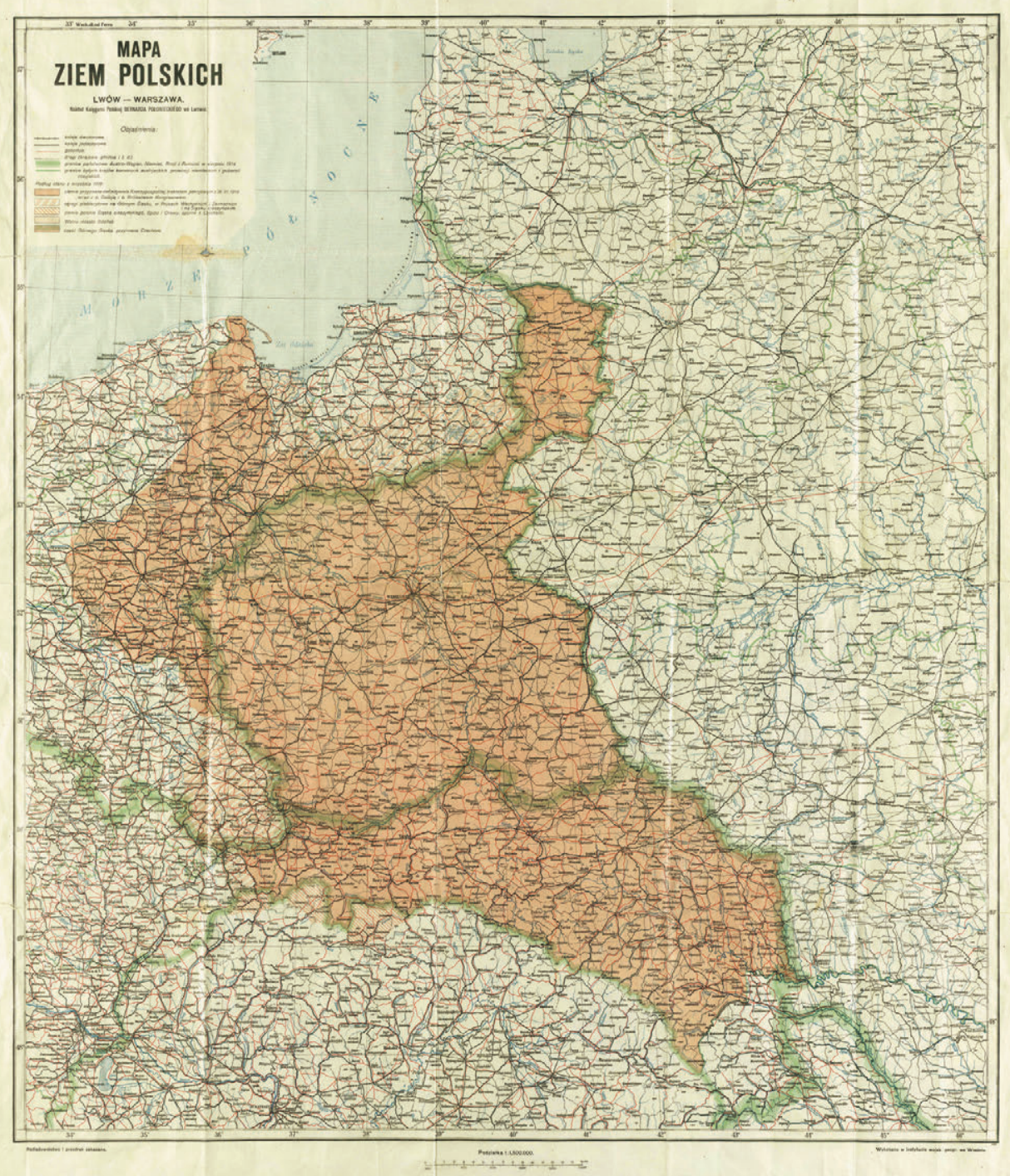

Ryc. 2. Mapa Ziem Polskich. Nakładem księgarni B. Połonieckiego Map of Polish lands. The Połoniecki Publishing House

Źródło: Mapa ziem polskich, 1920, nakład Księgarni Polskiej Bernarda Połonieckiego we Lwowie, Lwów-Warszawa; Biblioteka Uniwersytecka im. Jerzego Giedroycia w Białymstoku, sygn./call no K-1675.

Source: Mapa ziem polskich, 1920, print run of the Bernard Połoniecki Polish Bookship in Lvov, Lvov-Warsaw; Jerzy Giedroyć University Library in Białystok, call no. K-1675. 
całą Galicje, aż po Zbrucz. Ponadto oznaczono pomarańczowym szrafem tereny plebiscytowe na Śląsku Górnym i Cieszyńskim, na Orawie i Spiszu oraz w Prusach Wschodnich. Nie dołączono do wyznaczonego obszaru tzw. „ziem polskich” obwodu białostockiego, oraz wyraźnie zaznaczono granice zaborcze, które już wówczas miały wymowę historyczną.

Możliwe, że wiedza o tej mapie dotarła do Stanów Zjednoczonych, gdyż analogiczna mapa, ale z bardziej uproszczonym zarysem ziem polskich została nieznacznie później zamieszczona na łamach nowojorskiego „Kuryera Narodowego” (ryc. 3) ${ }^{12}$. Granica polsko-niemiecka została na niej wyznaczona również w sposób jednoznaczny. Zgodnie z werdyktem wersalskim ukazano obszary plebiscytowe. W granicach państwa polskiego poza Wielkopolską i wąskim korytarzem pomorskim znajduje się całe byłe Królestwo Polskie w granicach ustalonych na Kongresie Wiedeńskim oraz cała Galicja. Obwód białostocki wraz z całymi rozległymi terenami zabużańskimi, które już wówczas były wyzwolone przez wojsko polskie i były traktowane jako ziemie przynależne do Polski zostały usytuowane poza wschodnią granicą i określone je jako „ziemie okupowane przez wojska polskie”.

Postanowienia wersalskie nie mogły być już kwestionowane i polska granica zachodnia (z wyjątkiem obszarów plebiscytowych), których los nie był jeszcze rozstrzygnięty była już ostatecznie ustalona. Po tych decyzjach terytorialnych w końcu 1919 r. została opublikowana mapa pokazująca zarys terytorialny postulowanego państwa polskiego (ryc. 4). Był to załącznik do oficjalnego dokumentu zawierającego konkretne i ostateczne wskazania państw zwycięskiej koalicji wobec pokonanych Niemiec. Na tym ważnym ujęciu kartograficznym zakreślono obszary, które zakładano, że znajdą się w odrodzonej Polsce. Jednolitym, wyróżniającym się kolorem wyodrębniono stosunkowo duży zwarty obszar składający się z ziem zaboru pruskiego uzyskanych przez Polskę w Wersalu, wraz z Wolnym Miastem Gdańskiem, następnie terytorium tzw. „Kongresówki”, bez północnej części guberni suwalskiej, ale z rejonem białostockim, obejmującym trzy powiaty (białostocki, bielski i sokólski) oraz całą Galicje i polskie obszary etniczne na Śląsku Cieszyńskim. Zaznaczono w sposób odrębny obszary plebiscytowe. Następnie przy zastosowaniu różnorodnych linii ciągłych lub przerywanych zakreślono różnorodne granice zasięgów, obejmujących pewne prowincje lub rejony sporne, do których Polska ma uzasadnione uprawnienia. Linią południkową zakreślono projektowaną przez Komitet Narodowy w Paryżu wschodnią granicę Polski przebiegającą od Dźwiny na północy do Dniestru na południu. To rozgraniczenie przebiegało na wschód od Mińska i Kamieńca Podolskiego. Wykreślono granicę oddzielającą Polskę od Litwy. Mapa ta była podstawą do tworzenia koncepcji wariantowych dotyczących wschodniej granicy, oraz zestawem innych potencjalnych roszczeń terytorialnych państwa polskiego. Mapa podobnie jak poprzednie pokazuje krótki okres czasu, gdy Polska już miała uznaną granicę zachodnią a granica wschodnia była ciągle nie ustalona.

W grudniu 1919 r. Ludwik Szczepański opracował i wydał w wydawnictwie wiedeńskim Berndta mapę „Polska i państwa ościenne z granicami na zasadzie traktatów w Wersalu i St. Germain” (ryc. 5). Państwo polskie ma na niej interesujący obszar i granice. Kolorem niebieskim wydzielono odzyskane ziemie zaboru pruskiego, całą Galicje i ziemie Królestwa Polskiego z obwodem białostockim, ale bez północnej części guberni suwalskiej, mającej etniczny charakter litewski. Kolorem jasno niebieskim wyodrębniono kresy wschodnie, które wg Komitetu Narodowego powinny być przyznane Polsce. Obejmują one Ziemie

12 Mapa została zaprezentowana w jubileuszowym albumie (Skoczek, 2018, s. 190). Odnotowano mylnie, że powstała ona około 1921 r. Wiele dowodów rzeczowych świadczy, że została ona opublikowana znacznie wcześniej, Przypuszczalnie pod koniec 1919 r., gdyż prezentuje stan polityczny z drugiej połowy 1919 r. 


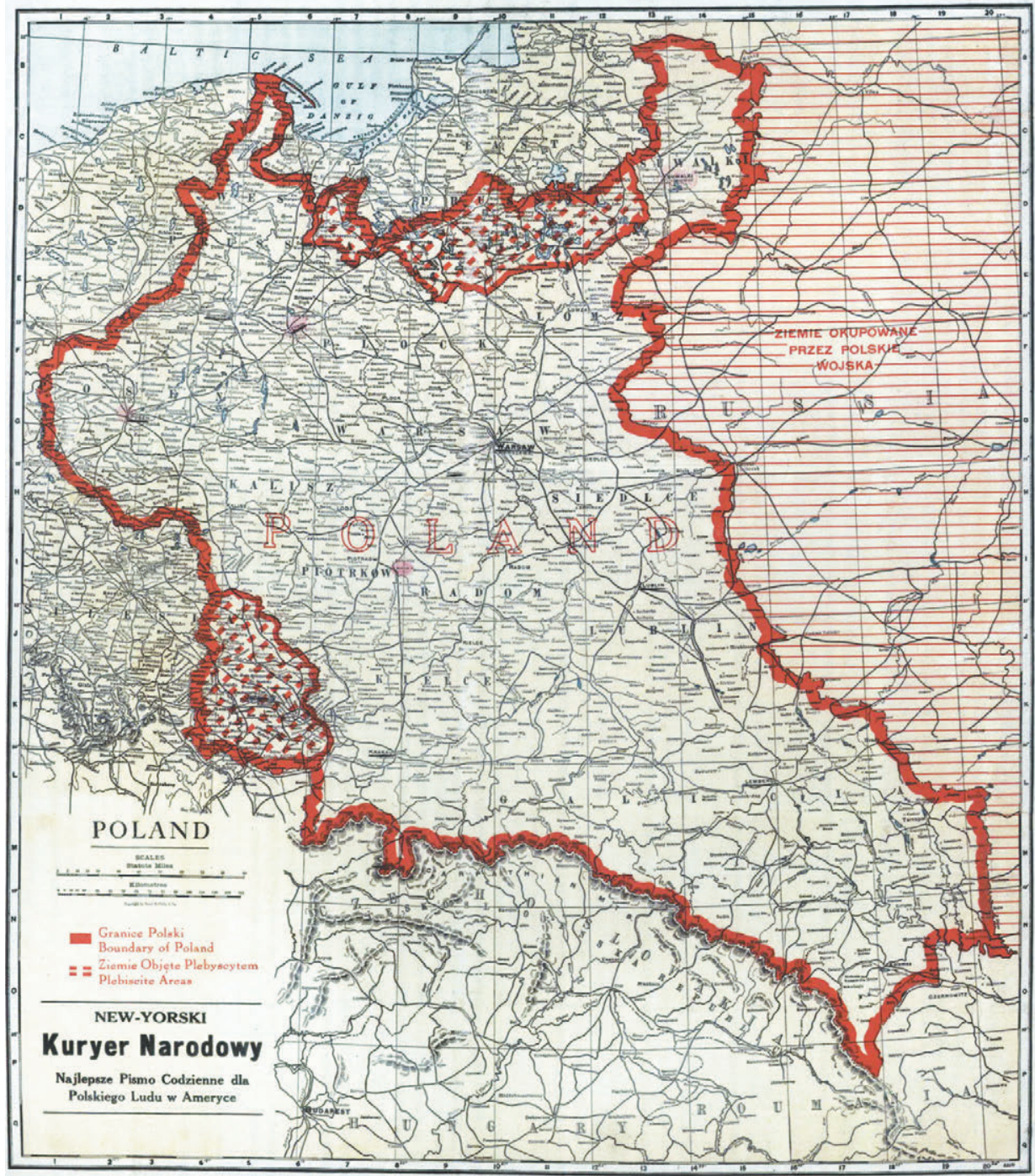

Ryc. 3. Nowa Mapa Polski The "New Map of Poland" Źródło: Nowa Mapa Polski, nakładem New-Yorskiego Kuryera Narodowego, New York, Biblioteka Narodowa, sygn. ZZK 18977.

Source: Nowa Mapa Polski, print run of the New York Kuryer Narodowy, New York, National Library, ref. ZZK 18977.

Mińską aż po Połock, Ziemie Wileńską, Inflanty Polskie, Polesie oraz Wołyń do rzeki Słucz i część Podola z Płoskirowem i Kamieńcem Podolskim. Granica wschodnia Polski pokrywa się z tzw. Linią Dmowskiego. Dodatkowo szrafem wyodrębniono obszary plebiscytowe.

Nieznacznie później, gdyż w styczniu 1920 r., w Warszawie opublikowano mapę autorstwa Edwarda Maliszewskiego i Tadeusza Szturm de Sztrema (ryc. 6). Określono na niej w sposób wyraźny granicę I Rzeczypospolitej z 1772 r. Zaznaczono również obszar tzw. 


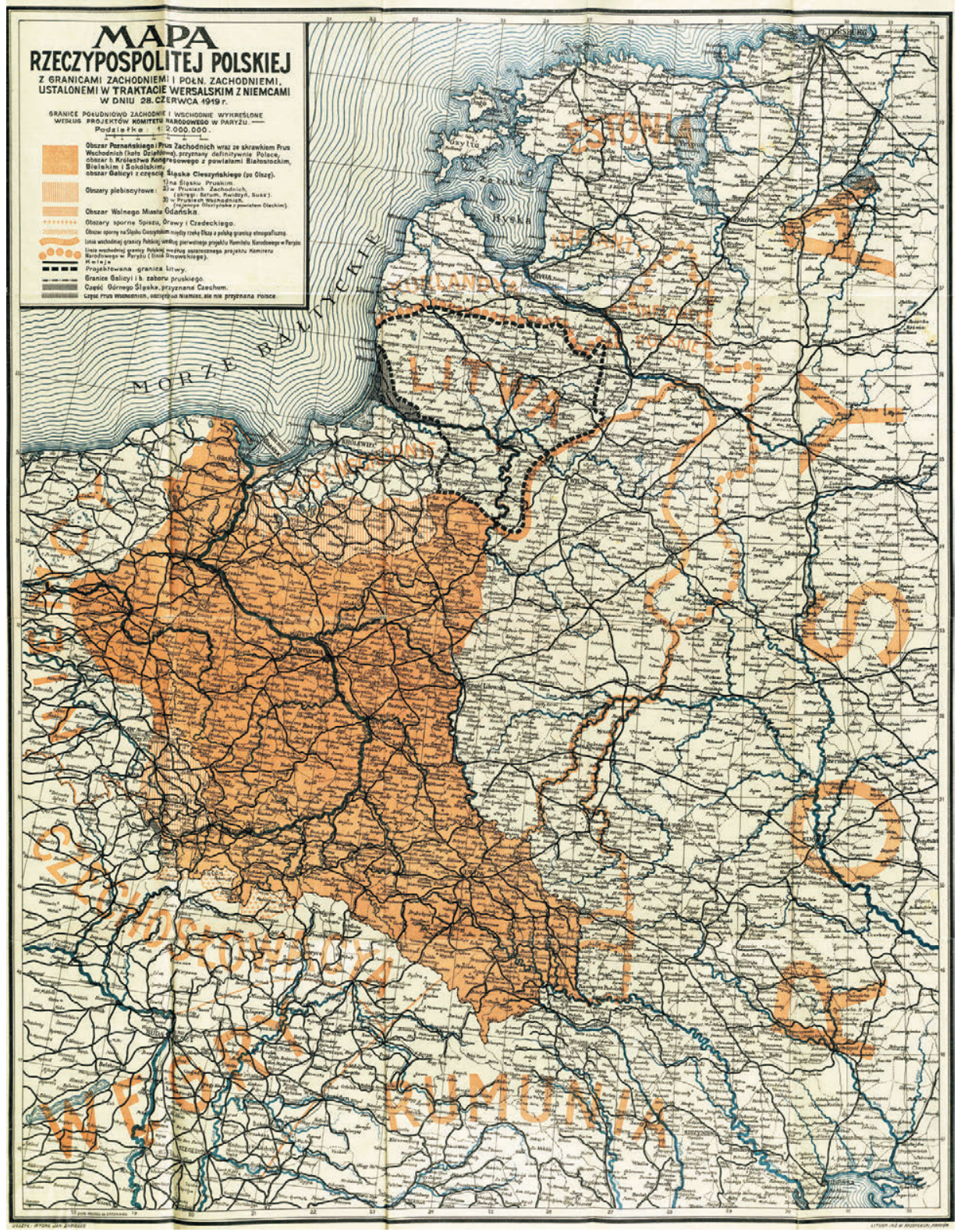

Ryc. 4. Mapa Rzeczypospolitej Polskiej z granicami zachodnimi i północnymi ustalonymi w Traktacie Wersalskim z Niemcami w dniu 28 czerwca 1919 r.

Map of the Republic of Poland with the western and northern borders established by the Treaty of Versailles with Germany on June 28th 1919

Źródło: Mapa Rzeczypospolitej Polskiej z granicami zachodniemi i północnemi ustalonemi w traktacie pokojowym z Niemcami z dokładnem uwydatnieniem obszarów plebiscytowych i terytoryum Woln. M. Gdańska, 1919, oprac. J. Zabiełło, wyd. Drukarnia E. i Dr. K. Koziańskich, Paryż, Kraków; CBGiOŚ. IGiPZ PAN, sygn.D.5100. Source: Mapa Rzeczypospolitej Polskiej z granicami zachodniemi i północnemi ustalonemi w traktacie pokojowym z Niemcami z dokładnem uwydatnieniem obszarów plebiscytowych i terytoryum Woln. M. Gdańska, 1919, drawn up by J. Zabiełto, publ. Drukarnia E. and Dr. K. Koziański, Paris, Kraków; CBGiOŚ. IGiPZ PAN, ref. D.5100. 


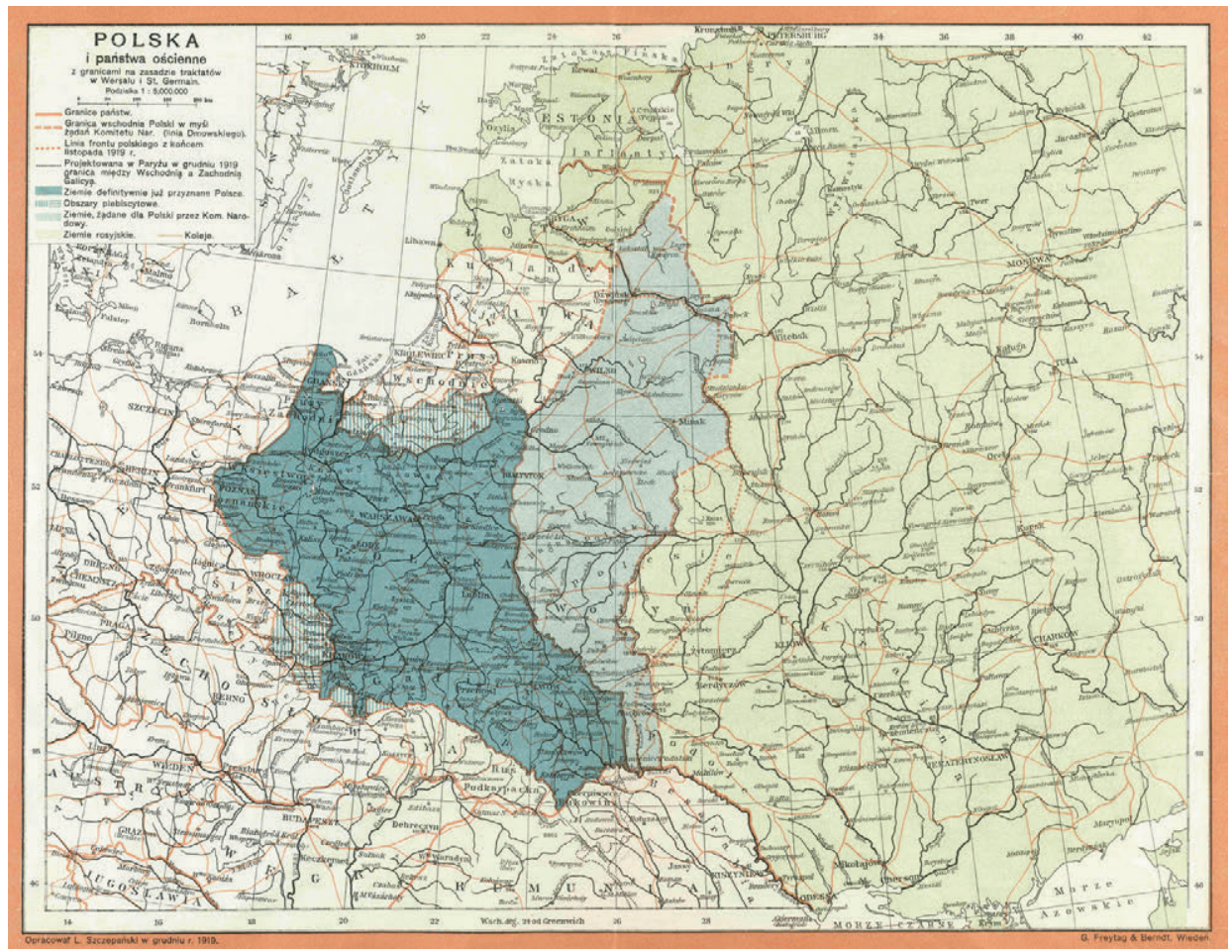

Ryc. 5. Polska i państwa ościenne z granicami na zasadzie traktatów w Wersalu i St. Germain: z uwydatnieniem obszarów plebiscytowych i linii frontu polskiego na wschodzie, 1919

Poland and the neighbouring states with borders by virtue of the Treaties of Versailles and St. Germain: with highlighting of the plesbiscite areas and Polish Front Line in the East in 1919

Źródło: Polska i państwa ościenne: z granicami na zasadzie traktatów w Wersalu i St. Germain, 1920, oprac. L. Szczepański, Wyd. L. Szczepański, G. Freytag and Berndt, Kraków-Wiedeń; CBGiOŚ. IGiPZ PAN, sygn. D.11577. Source: Polska i państwa ościenne: z granicami na zasadzie traktatów w Wersalu i St. Germain, 1920, drawn up by L. Szczepański, publ. L. Szczepański, G. Freytag \& Berndt, Kraków-Vienna; CBGiOŚ. IGiPZ PAN, ref. D.11577.

Królestwa Kongresowego i Galicji. Nie oddzielono Litwy, która już wówczas ogłosiła niepodległość. Zakreślono rozgraniczenie polsko-niemieckie ustalone w Wersalu. Zaznaczono ponadto linie frontu polsko-bolszewickiego, który wówczas przebiegał na wschód od Mińska Litewskiego, Bobrujska i Kamieńca Podolskiego. Na mapie kolorem czerwonym wyodrębniono obszary zamieszkałe przez ludność polską. Zasięg przewagi liczebnej Polaków i został określony w sposób maksymalistyczny. Autorzy starali się ukazać terytorium wobec, którego Polska ma uzasadnione prawa nie tylko historyczne ale i etniczne. Na mapie zaznaczono przy wykorzystaniu polskiego nazewnictwa układ powiatowy istniejący do wojny. Pominięto układ dawnych jednostek administracyjnych szczebla wyższego (guberni, rejencji czy też prowincji). Autorzy wiedzieli już o decyzji wprowadzenia nowych jednostek wojewódzkich, ale ich imiennie nie określono.

W ramach kraju konsekwentnie wprowadzano nowy ład administracyjny. Po formalnym uzyskaniu części zaboru pruskiego, nie było wątpliwości, ze stolicą Wielkopolski czyli województwa poznańskiego będzie Poznań. Większe komplikacje dotyczyły województwa pomorskiego. Początkowo stolicą tego województwa został Poznań, w którym w paździer- 


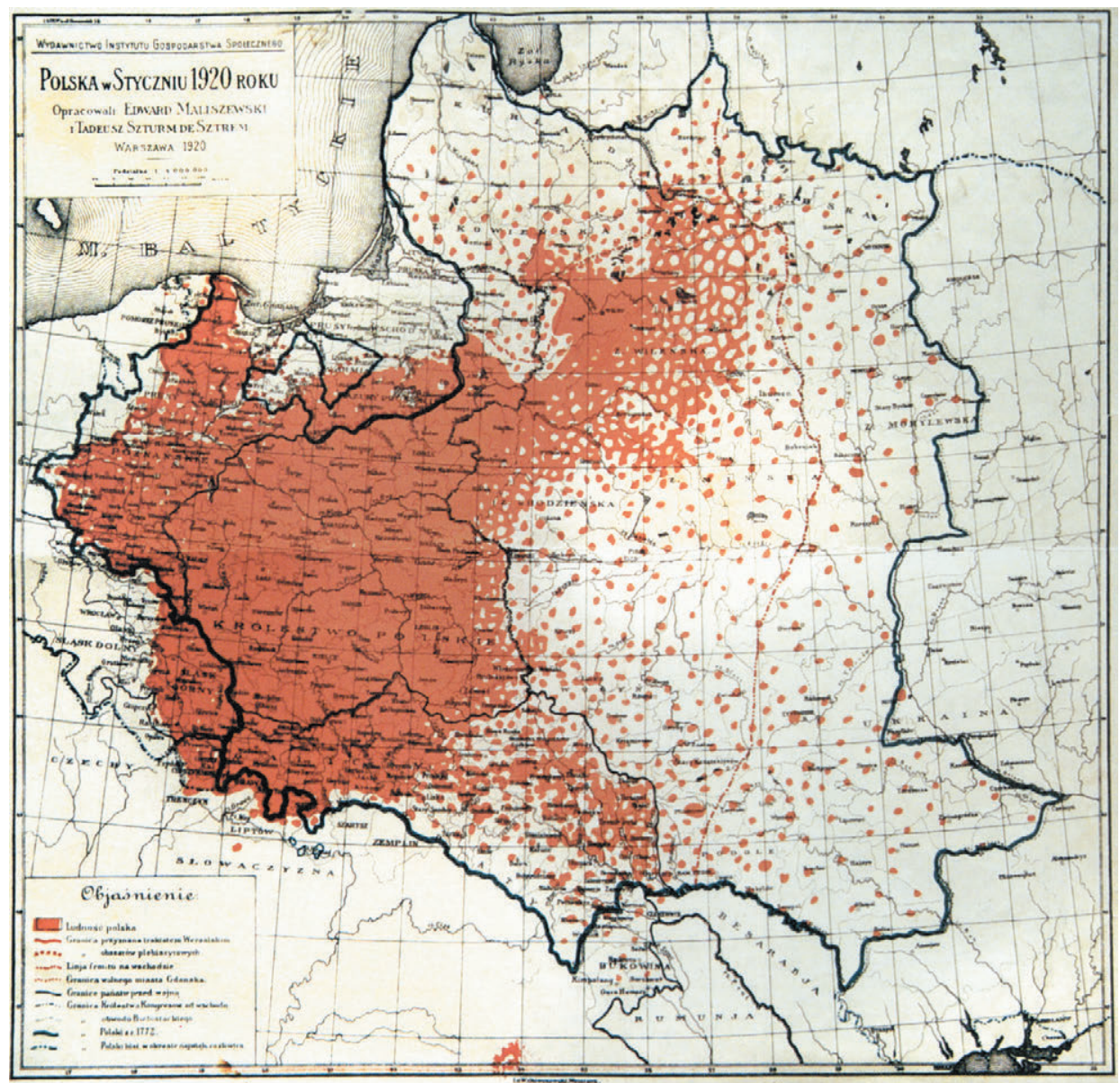

Ryc. 6. Polska w styczniu 1920 r.

The "Poland in January 1920"

Źródło: Polska w styczniu 1920 roku, 1920, oprac. E. Maliszewski i T. Szturm de Sztrem, Wydawnictwo Instytutu Gospodarstwa Społecznego, Warszawa; CBGiOŚ. IGiPZ PAN, sygn. PTG D.659.

Source: Polska w styczniu 1920 roku, 1920, drawn up by E. Maliszewski and T. Szturm de Sztrem, Wydawnictwo Instytutu Gospodarstwa Społecznego, Warsaw; CBGiOŚ. IGIPZ PAN, ref. PTG D.659.

niku 1919 r. umieszczono władze województwa pomorskiego. Dopiero stopniowo przenoszono urząd wojewódzki do Torunia. Wybrano to miasto a nie Bydgoszcz, ponieważ przeważała tam jeszcze niezbyt lojalna ludność narodowości niemieckiej. Przeniesiono również do Torunia urzędników polskich z Gdańska, pracujących w tzw. Polskim Podkomisariacie. Województwo pomorskie objęło 62\% prowincji Prusy Zachodnie i powiat działdowski z prowincji Prusy Wschodnie (Sudziński, 2003, s. 103). Stolica województwa pomorskiego w Toruniu faktycznie została ustanowiona dopiero 20.01.1920 r, wraz z wkroczeniem do tego miasta wojsk polskich.

Pokonanie Armii Czerwonej w Bitwie Warszawskiej oraz w operacji niemeńskiej umożliwiło podjęcie rokowań pokojowych z bolszewicką Rosją. Zawarto pokój i rozpoczęły się 
pertraktacje graniczne, które zakończyły się podpisaniem pokoju ryskiego. W początkowej fazie tych dwustronnych ustaleń, było już wiadomo w ogólnym zarysie, jak będzie wytyczona granica wschodnia. Znając te informacje znany polski geograf Eugeniusz Romer wykreślił, opublikował i rozpowszechnił w końcu 1920 r. administracyjną mapę Polski (ryc. 7). Było to już pierwsze ujęcie kartograficzne Polski w nowych granicach politycznych (wersalsko-ryskich). Granica wschodnia była pokazana w dwóch minimalnie różniących się wariantach. Na granicy zachodniej zaznaczono już werdykt dotyczący podziału Górnego Śląska, jedynie granica polsko-litewska została wytyczona jako rozgraniczenie tymczasowe. Na mapie wyznaczono wszystkie ponumerowane jednostki powiatowe. Ze względu na brak ostatecznych decyzji odniesionych do ziem wschodnich, nie podzielono całego kraju na jednostki szczebla wojewódzkiego.

Znacznie dłużej trwały ustalenia dotyczące podziału administracyjnego byłego zaboru austriackiego. Uregulowano tę kwestie ustawą z dn. 3.12.1920 r. zatytułowaną" O tymczasowej organizacji władz administracyjnych II instancji (wojewódzkiej) na obszarze b. Królestwa Galicji i Lodomerii z Wielkim Księstwem Krakowskim oraz na wchodzących w skład Rzeczypospolitej Polskiej obszarach Spisza i Orawy" tworząc na tych obszarach województwa: krakowskie, Iwowskie, stanisławowskie i tarnopolskie. Ten układ administracyjny zaczął obowiązywać od 1.09.1921 r. a w raz z nim ustały uprawnienia Generalnego Delegata Rządu oraz Namiestnika we Lwowie, zaś administracją zaczęli kierować wojewodowie przy pomocy urzędów wojewódzkich (Leszczyńska, 1990, s. 44). Przy ustaleniu wewnętrznych granic między województwami kierowano się w dużym stopniu uwarunkowaniami narodowościowymi. Granicę zachodnią województwa Iwowskiego przesunięto daleko na zachód, aby objąć kilka powiatów rdzennie polskich, zaś województwa tarnopolskie tak wykrojono, aby ograniczyć odsetek ludności ukraińskiej.

Kolejnym województwem powołanym na podstawie ustawy konstytucyjnej uchwalonej 15.07.1920 r. było województwo śląskie. Obejmowało ono część Śląska Cieszyńskiego oraz wschodnią część Górnego Śląska. Ten ostatni, z niewielkimi fragmentami nie należał dawniej do I Rzeczypospolitej a o jego przynależności do Polski względnie Niemiec miał zadecydować plebiscyt. Po jego przeprowadzeniu i trzech powstaniach śląskich nastąpił podział Górnego Śląska. W rezultacie decyzji mocarstw zachodnich na Konferencji w Spaa nastąpił również podział Śląska Cieszyńskiego. W związku z tymi narzuconymi decyzjami jedynie północno-wschodnia część Śląska Cieszyńskiego została oficjalnie przyłączona do Polski 28.07.1920 r., zaś wschodnie rejony Górnego Śląska dopiero 15.06.1922 r. Utworzone województwo śląskie uzyskało szeroką autonomię.

Wojna polsko-bolszewicka utrudniała uporządkowanie i ostateczne ustalenie stałej polskiej administracji na Kresach Wschodnich. W zasadzie dopiero po wyparciu bolszewików i zakończeniu Konferencji Pokojowej w Rydze można było podjąć wiążące ustalenia. Ustawą z 4.02.1921 r. utworzono na tych ziemiach trzy województwa: wołyńskie ze stolicą w Łucku, nowogródzkie z ośrodkiem wojewódzkiej administracji ulokowanej w Nowogródku oraz województwo poleskie. Stolicą tego ostatniego miał być początkowo centralnie położony Pińsk, lecz ze względu na trudności lokalowe przeniesiono urząd wojewódzki do peryferyjnie położonego Brześcia Litewskiego (później zwanego Brześciem nad Bugiem). Ostatnim powołanym województwem było województwo wileńskie ze stolicą w Wilnie. Do wyborów Sejmu Wileńskiego w 1922 r. nazywane było Ziemią Wileńską lub Wleńskim Okręgiem Administracyjnym. Przynależność tego terytorium długo była nierozstrzygnięta. Dopiero po znanych wydarzeniach i konflikcie polsko-litewskim wybrany Sejm Wileński podjął zatwierdzoną przez 


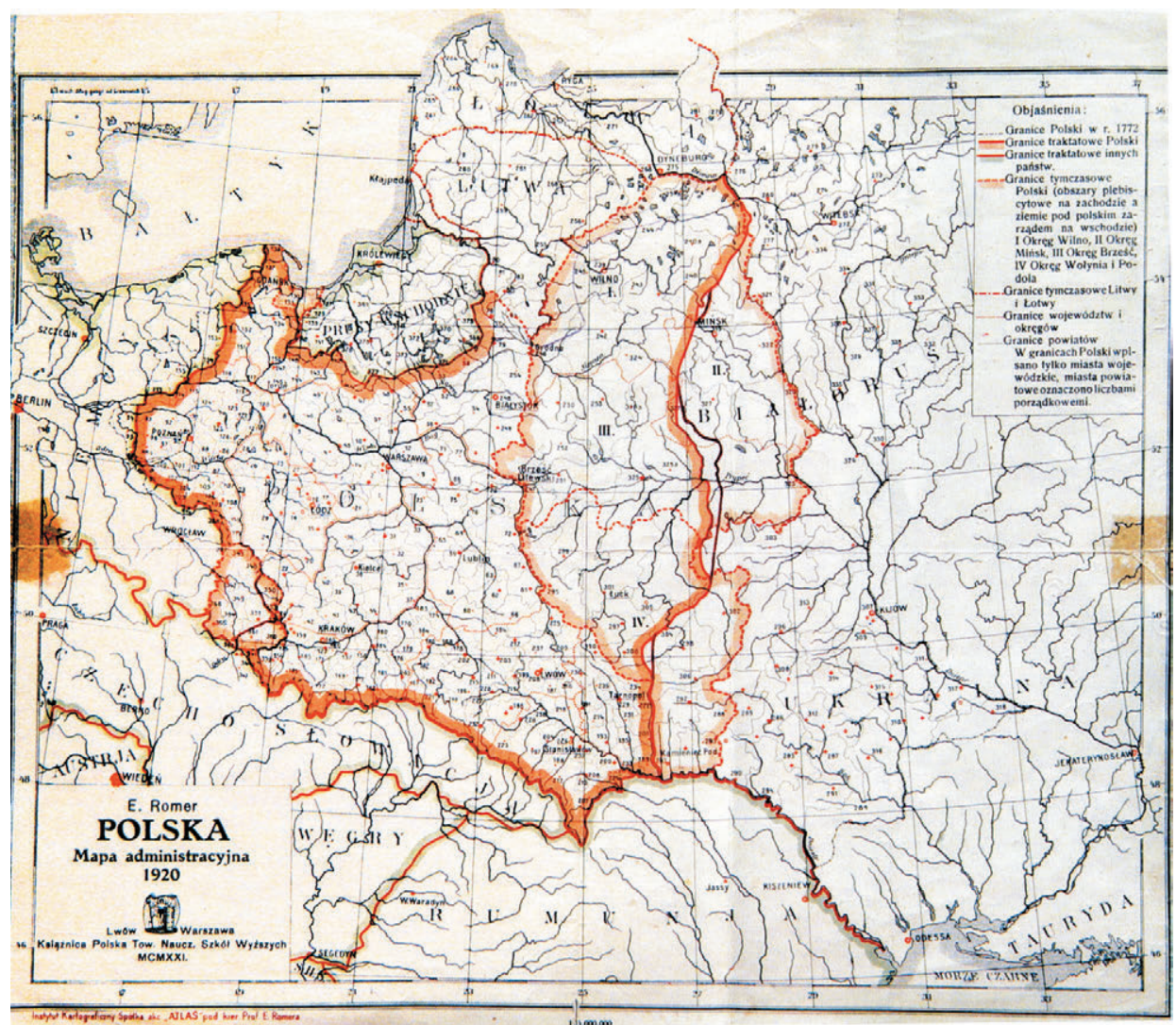

Ryc. 7. Polska. Mapa administracyjna $1920 \mathrm{r}$.

Poland. 1920 Administrative map

Źródło: Polska. Mapa administracyjna 1920, 1921, oprac. E. Romer, wyd. Książnica Polska Tow. Naucz. Szkół Wyższych Lwów-Warszawa; CBGiOŚ. IGiPZ PAN, sygn. D.5382 / Source: Polska. Mapa administracyjna 1920, 1921, drawn up by E. Romer, publ. Ksiq̨żnica Polska Tow. Naucz. Szkół Wyższych Lwów-Warszawa; CBGiOŚ. IGiPZ PAN, ref. D.5382.

Sejm Ustawodawczy 24.03.1922 r. uchwałę o przyłączeniu tzw. Litwy Środkowej do Rzeczypospolitej Polskiej (Kumaniecki, 1924, s. 597-603). Ustalanie więc podziału administracyjnego Polski trwało ok. czterech lat. Ostatecznie wyznaczono 16 jednostek wojewódzkich oraz dodatkowo miasto stołeczne Warszawę jako odrębną jednostkę szczebla wojewódzkiego ${ }^{13}$.

Wspomniane wydarzenia historyczne umożliwiły już przedstawienie w ujęciu kartograficznym państwa polskiego w ściśle wytyczonych granicach politycznych, uznanych przez sąsiadów i społeczność międzynarodową ${ }^{14}$. W zasadzie takim werdyktem symbolicznym, po podziale obszarów plebiscytowych, była decyzja Rady Ambasadorów z 15.03.1923 r. zatwierdzającą polską granicę wschodnią, w tym przynależność do Polski całej Galicji. W zasadzie po tym formalnym uznaniu, publikowane mapy administracyjne

\footnotetext{
${ }_{13}$ Podział ten wzbudził wiele kontrowersji i dyskusji. Warto tu wspomnieć o koncepcjach takich autorów jak Wakar (1925), Langrod (1931) i Ziomek (1931). Litewska.

14 Jedynym państwem nie uznającym werdyktu granicznego i przynależności Wilna do Polski była Republika
} 
mogły już jednoznacznie ukazywać nie tylko granicę zewnętrzne Polski, ale również ustalony podział administracyjny kraju na jednostki wojewódzkie. Map tego rodzaju powstało już wiele. Można założyć, że pierwsza z nich powstała, jeszcze przed werdyktem Rady Ambasadorów, gdyż w połowie 1921 r. (ryc. 8) ${ }^{15}$. Pokazuję ona jeszcze wyodrębnioną tzw. Litwę Środkową i podzielony Górny Śląsk na część polską i niemiecką. Następnie już wydane atlasy lub mapy (np. E. Romera lub J.M. Bazewicza) mogły określać granice polityczne lub administracyjne w sposób taki jaki przetrwał aż do wybuchu II wojny światowej. Są one znane i popularne, więc nie zachodzi potrzeba ich prezentować.

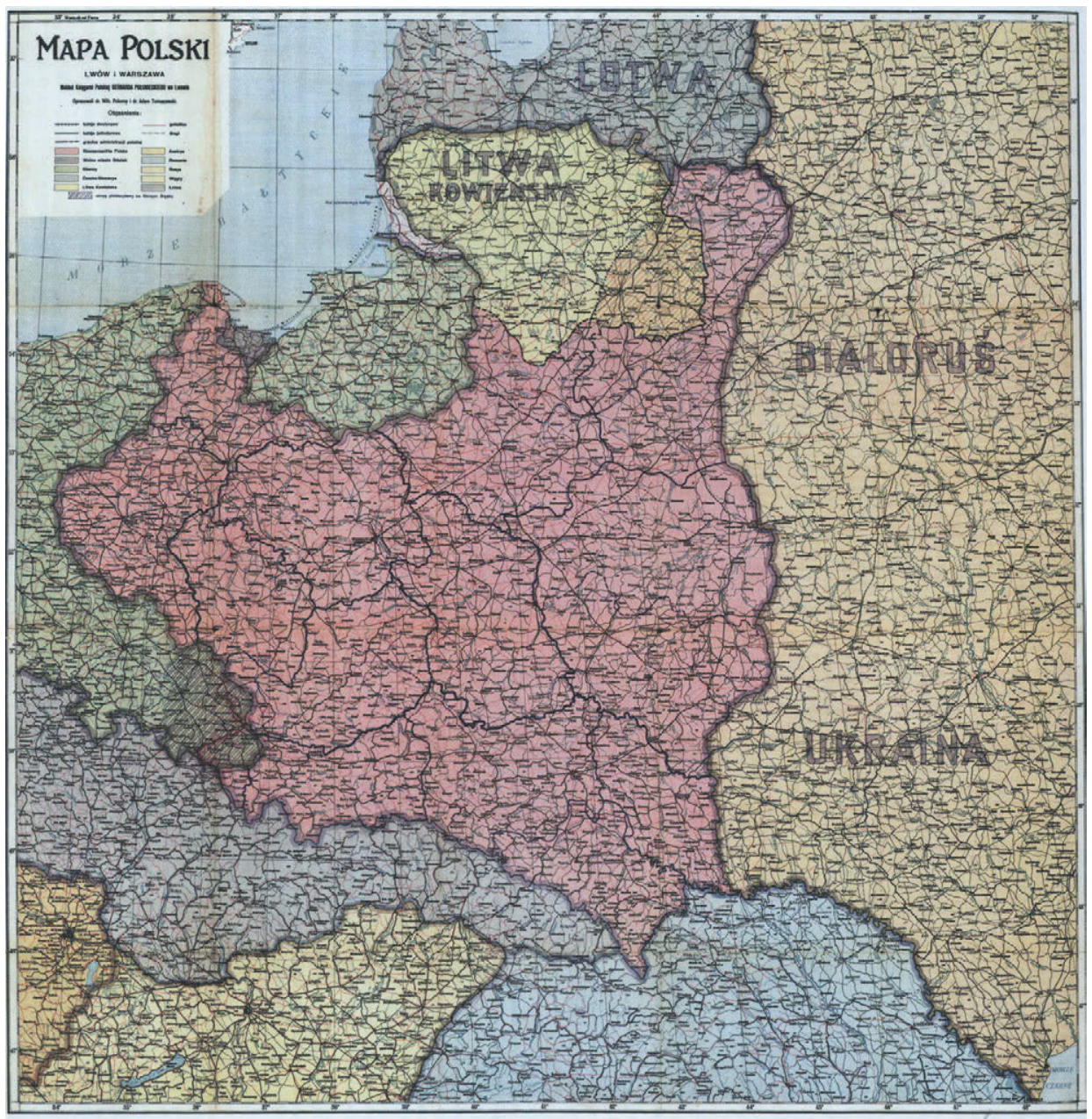

Ryc. 8. Mapa Polski przed $1920 \mathrm{r}$.

Map of Poland pre-1920

Źródło: Mapa Polski, 1921, Biblioteka Narodowa, sygn. ZZK 46 090, oprac. W. Pokorny, A. Tomaszewski, Nakład Księgarni Polskiej Bernarda Połonieckiego, Lwów, Warszawa / Source: Mapa Polski, 1921, National Library, ref. ZZK 46 090, drawn up by W. Pokorny and A. Tomaszewski, Print run of the Bernard Połoniecki Polish Bookshop, Lvov, Warsaw.

15 Oryginał zamieszczonej mapy znajduję się w Bibliotece Narodowej, reprodukcja zaś w albumie Polonia Restituta 1918-1921 (Skoczek, 2018, s. 186). 


\section{Podsumowanie}

Sytuacja polityczna w ciągu czterech brzemiennych lat (1918-1921) była niestabilna. Nie było wiadomo jakie będą granice zewnętrzne odrodzonego państwa. Jednocześnie pojawiały się poważne kontrowersje, co do wewnętrznego układu administracyjnego. Istniały różne budzące wątpliwości poglądy, które ujawniały się w sejmie, rządzie oraz w bieżącej publicystyce (szerzej: Eberhardt, 2004). Dotyczyło to zarówno liczby jednostek wojewódzkich ich granic i kompetencji a nawet wyboru ośrodków wojewódzkich. Ostateczny kształt uformowanego państwa polskiego o wyznaczonych ściśle granicach politycznych i administracyjnych ukazał dopiero pierwszy powojenny atlas geograficzny (Romer, 1921).

W okresie tak niepewnym politycznie wykreślane były mapy polityczno-administracyjne Polski. Są one ważnym a niedocenianym dokumentem historycznym, zdaniem autora niniejszego artykułu nawet w środowisku polskich geografów. Z okazji stulecia niepodległości celowe jest zatem ich przypomnienie oraz spojrzenie na nie od strony kartograficznej. Mapy te są w stanie wyjaśnić wiele kwestii nie w pełni dostrzeganych i docenianych. Poza walką o zjednoczenie kraju i jego korzystne granice polityczne, problematyka związana z unifikacją i integracją kraju po stuletniej niewoli stanowiła najważniejsze wyzwanie dla elity politycznej tworzącej państwowość polską. To zadanie zostało w sposób w miarę optymalny spełnione, co świadczyło o dużej dojrzałości ideowej i politycznej ówczesnego społeczeństwa polskiego. Działo się to w sytuacji pełnej destabilizacji politycznej i militarnej na ziemiach polskich między 1918 a 1921 r. Scenariusze prawdopodobnych wydarzeń mogły być bardzo różne, gdyż Polska mogła się odtworzyć jako namiastka Księstwa Warszawskiego, jak też uformować się jako stosunkowo duże państwo europejskie. Istniała nawet groźba, że w przypadku klęski w sierpniu 1920 r. pod Warszawą nastąpiłoby unicestwienie państwa polskiego. Równocześnie zachodziły bardzo istotne przeobrażenia wewnętrzne, mające na celu unifikacje kraju i utworzenie silnego unitarnego państwa. Starano się konsekwentnie przezwyciężyć wszelkie partykularyzmy dzielnicowe, w imię wspólnego dobra jakim było niepodległe i zjednoczone państwo polskie. Tych przypomnianych osiem ujęć kartograficznych pokazuję skalę trudności, wynikających nie tylko z zagrożenia zewnętrznego, ale również ze zróżnicowania regionalnego kraju i istniejących różnic i dysproporcji dzielnicowych.

\section{Piśmiennictwo}

Ajnenkiel A., 1972, Spór o model parlamentaryzmu polskiego, Książka i Wiedza, Warszawa.

Ajnenkiel A., 1982, Ustrój i prawo II Rzeczypospolitej, [w:] J. Tomicki (red.), Polska Odrodzona 1918-1939, s. 55-127.

Bukowiecki S., 1922, Polityka Polski Niepodległej, Stowarzyszenie Wydawnicze Ignis, Warszawa.

Dmowski R., 1925, Polityka polska i odbudowywanie państwa, Księgarnia Perzyński, Niklewicz i s-ka, Warszawa.

Eberhardt P., 2004, Polska i jej granice. Z historii polskiej geografii politycznej, Wydawnictwo Uniwersytetu M. Curie-Skłodowskiej, Lublin.

Eberhardt P., 2018, Kształtowanie się koncepcji granic politycznych I/ Rzeczypospolitej, [w:] A. Jackowski (red.), Rola geografii w utrwalaniu niepodległej Polski i w jej rozwoju, Instytut Geografii i Gospodarki Przestrzennej UJ, s. 11-42. 
Kozłowski A.R., 2008, Rok 1918 - niezapomniany pokój brzeski, [w:] P. Eberhardt, Problematyka geopolityczna ziem polskich, Prace Geograficzne, 218, IGiPZ PAN, Warszawa, s. 163-186.

Kuklinski A., Swianiewicz P., 1990, Polskie województwo. Doświadczenia i perspektywy. (w:) A.Kukliński, P. Swianiewicz (red.), Polskie województwo. Doświadczenia i perspektywy, Instytut Gospodarki Przestrzennej UW, 23, s. 9-38.

Kumaniecki K.W., 1921, Ustrój państwowych władz administracyjnych na ziemiach Polski, Wyd. L. Frommer, Kraków.

Kumaniecki K.W., 1924, Odbudowa państwowości polskiej. Najważniejsze dokument, Wyd. Jana Czernickiego, Warszawa.

Kutrzeba S., 1921, Polska Odrodzona, Wyd. Gebethnera i Wolffa, Kraków.

Langrod J.S., 1931, Ze studiów nad podziałem administracyjnym państwa, Wyd. Gebethnera i Wolffa, Kraków.

Leszczyńska C., 1990, Województwo w II Rzeczypospolitej, [w:] P. Kukliński, A. Swianiewicz (red.), Polskie województwo. Doświadczenia i perspektywy, Instytut Gospodarki Przestrzennej UW, 23, s. 39-114.

Łossowski P., 1998, Jak feniks z popiołów: oswobodzenie ziem polskich spod okupacji niemieckiej, Mazowiecka Wyższa Szkoła Humanistyczno-Pedagogiczna, Łowicz.

Piszczkowski T., 1969, Odbudowanie Polski 1914-1921: historia i polityka, Księgarnia Polska Orbis, Londyn.

Pobóg-Malinowski W., 1967, Najnowsza historia polityczna Polski 1914-1939, Wyd. B. Świderski, Londyn.

Romer E. (red.), 1916, Geograficzno-statystyczny atlas Polski, Wyd. Gebethnera i Wolffa, Warszawa, Kraków.

Skoczek T. (red.), 2018, Polonia Restituta 1918-1921, Wyd. Muzeum Niepodległości, Warszawa.

Sudziński R., 2003, Miejsce Pomorza w koncepcjach podziału terytorialnego Drugiej Rzeczypospolitej, [w:] Z. Karpus, M. Wojciechowski (red.), Drogi do niepodległości. Ziemie polskie w dobie odbudowy Państwa Polskiego, Wydawnictwo Naukowe UMK, s. 99-112.

Szwarc A., Turkowski R. (red.), 2000, Źródła do dziejów Polski w XIX i XX wieku. Wybór tekstów źródłowych. T. 2, Lata 1864-1918, Wyższa Szkoła Pedagogiczna, Pułtusk.

Topolski J. (red.), 1981, Dzieje Polski, Państwowe Wydawnictwo Naukowe, Warszawa.

Trzebiński W., 1956, Podział administracyjny Królestwa Polskiego w okresie 1815-1919, Dokumentacja Geograficzna, 4, Instytut Geografii PAN, Warszawa.

Wapiński R., 1995, Komitet Narodowy Polski i jego wkład w odbudowę niepodległości Polski (1917-1919), [w:] Cz. Bloch, Z. Zieliński (red.), Powrót Polski na mapę Europy, Katolicki Uniwersytet Lubelski, Lublin, s. 199-252.

Ziomek M.J., 1931, Podział państwa dla celów administracji ogólnej z punktu widzenia potrzeb życia gospodarczego, [w:] Kraków stolica kresów południowo-zachodnich, studia nad nowym podziatem państwa (praca zbiorowa), Izba Przemysłowo-Handlowa, Kraków, s. 241-308.

\section{Summary}

This article pursues an analysis seeking to explain how political borders and administrative boundaries took shape in the Polish state that came back into being at the end of the First World War. This was a continuing period of instability from a military point of view, given the ongoing war with Bolshevik Russia (which continued through to 1920). The further 
investigation of this subject matter is assisted by the presentation here of cartography in the form of 8 original maps coming into being at that historic time. The first map dates from early 1919 - as first elections to the Legislative Sejm were pending. It thus shows constituencies (electoral districts) which at that time coincided with the country's (county-level) units of administration. The presentation of this little-known (in essence now-forgotten) cartographic configuration offers a starting point for the further consideration of the political borders and administrative division that took shape in the newly-reborn Poland. Further historical maps included in the text thus show the Polish state with borders as variously construed, in what were a mixture of both authors' concepts as to how these ought to look and borders actually existing at the given time and adjusted to the political situation of the given moment. These were thus limits set by military action, in the context of the armed conflicts that broke out with the polities neighbouring with Poland. The map included last in the text came out in 1921. It presents Poland's political and administrative layout in the wake of the entry into force of the Treaty of Versailles, as well as in line with the provisions of the Treaty of Riga definitively setting the course of Poland's eastern border. Also marked out on it is the internal division of the country into units at voivodeship level, as had been decided upon by the authorities of the independent Polish state. In essence, it was the political and administrative borders and boundaries established at that time that would persist unchanged through to 1938. 